\title{
Buddhist Logic Expounded by Means of Symbolic Logic
}

Hajime Nakamura

Professor of Indian and Buddhist Philosophy

\section{Part I : EXPOSITION OF VOIDNESS BY MEANS OF SYMBOLIC LOGIC}

\section{I}

The study of logic should be of a universal nature. In actuality, however, it is a historical fact that the logical system which arose is conditioned for some reason by its historical and sociological environment out of which the logicians were born. Thus also it can be thought that "hetu-vidyā", namely Buddhist logic, has also probably received influences and limitations from the basic truths of Buddhism and its fundamental standpoints. Therefore present day symbolic logic will be used here as the field in which these issues can be best understood. The study of traditional Indian logic has been based on traditional formal logic, the so-called "Aristotelean logic" originating in Aristotle and completed by the logicians of the Middle Ages. However, because this logic was based on the various European languages and formulated, there are many points where it has received its restrictions. It has meaning in that it offers material as one trend of logic in the field of comparative study. To make this the standard in this present age, however, is not appropriate any longer. That standard must be sought in the modern logic, namely symbolic, mathematical, or exact logic.

The necessity for this sort of research has already been advocated by St. Schayer of Poland and recently, Prof. Daniel H. H. Ingalls of

(1) St. Schayer: Über die Methode der Nyāya-Forschung (Festschrift Moritz Winternitz, Leipzig 1933. S. 147-257).

St. Schaper: Anfänge der Aussagenlogik in Indien (Bulletin de l'Académie Polonaise des Sciences et des Lettres, Cracovie, 1933. This was not available to me.) 
Buddhist Logic Expounded by means of Symbolic Logic (H. Nakamura)

Harvard has shown significant results pertaining to the Navya-Nyāya Logic. The writer would like to use symbolic logic as one kind of litmus paper and test it to Buddhist logic. That is to say, let us try to treat and express Buddhist logical thought by applying to it the mathematical forms of symbolic logic. Then the inconsistencies and the important differences will be seen between this and the present day logician's general interpretations. With this as the key I would like to elucidate the special charcteristics of Buddhist logical thought and consider the influence of Voidness (Śñuyatā) in Buddhist thought on it.

Of course symbolic logic was born out of, and manifested from, the foundation of Western thought. In India also symbolic thought existed, however it seems not to have appeared ultimately as thought relying on symbols as variables. (This point will be discused on another occassion and will be omitted here.) Therefore even in our present designated investigation, the fact that an analysis of Eastern thought is being attempted with a product of Western thought canot be avoided. At present symbolic logic, however, has become vastly improved and rather advanced. It is separated from the restrictions of the various existing languages, and because of this, if it is truly favorable for the sake of understanding Indian, thought, clearly as well as Indian logic, then it should after all be relied upon. Because the Indian logicians of the past were studied from the standpoint of Western traditional logic, it has been thought that the system of Indian logic was very irregular. If examined, however, from the standpoint of recent logic, it is not irregular in the least, and quite to the

(2) Daniel Henry Holmes Ingalls: Materials for the Study of Navya- Nyāya Logic. Harvard Oriental Series, vol. 40. Cambridge, Mass., 1951.

D.H.H. Ingalls : Samkara on the Question : Whose is avidyā ?-Philosophy East and West, vol. III, no. I, 1953, pp. $69 \mathrm{f}$. (In the idea of avidya of Śamkara, Ingalls holds that here is the germ of the multi-valued logic. If this argument is upheld, then the same significance can be held for the avidya of Buddhism.)

(3) Again the logic of India did not bind itself to mathematics but rather tied in with grammar and developed. (Ingalls: The Comparison of Indian and Western Philosophy. The Journal of Oriental Research Madras, XXII, 1954, p. 1 f.) 


\section{(3) Buddhist Logic Expounded by means of Symbolic Logic (H. Nakamura)}

contrary shows clearly cases where Western traditional logic held firmly to unnecessary regulations. Some actual examples of this will be indicated here.

In the traditional logic based on Aristotle, concepts had to be álways expressed in the nominative case. In the syllogisms of India, there are very many cases where in much the same manner it is expressed in the nominative. For example, in the syllogism where one whould know the existence of fire by seeing smoke it is said: "This mountain is something that has fire." (parvato 'yam vahnimān) However, assertive propositions are frequently expressed in this syllogism as in the sentence; "fire is here" (agnir atra). In an oridinary Sanskrit grammar book it is explained that "fire" ist he subject and " is here" is the predicate. However, according to the Indian logicians, "here" (atra) is the subject (pakșa) of this assertive proposition. In the eyes of persons who are accustomed to the traditional logical system of the West, this form of expression of India would appear to be very complex. (In short, in the traditional logic of the West, the former is a subsumptional judgement and the latter an existential judgement.)

However, from the standpoint of recent logic, this is not in the least strange. In the standpoint of Boole's logical algebra as well as Schröder's, if "smoke" is expressed as " a", and "fire" as " $b$ ", the sentence can be indicated by

$$
-a+b=1 \quad \text { and again } \quad a<b
$$

(The meaning which expresses the form of the first proposition is as follows: "All things that are not "a" are again "b".)

Again if another form is used, it is expressed as:

$$
a-b=0 \quad \text { (There is nothing which is a and not b.) }
$$

(4) Carl Prantl: Geschichte der Logik im Abendlande, Bd. I, S. 302

(5) e. g. Tarkabhāṣā, s.v. avayavāḥ. cf. Tarkasaṃgraha, Anumānapariccheda.

(6) The Nyāyapravśa. Part I. Sanskrit Text with Commentaries. Ed. by Anandshankar Dhruva. Baroda, Oriental Institute, 1930. Sanskrit Text, p. 7. agnir atra, dhūmāt (Nyāyabindu II, 18).

(7) C. I. Lewis and C. H. Langford: Symbolic Logic, New York, Dover Publications, Inc., 1932. p. 34. 
Buddhist Logic Expounded by means of Symbolic Logic (H. Nakamura)

$\mathrm{ab}=0 \quad$ (If something is a and also $\mathrm{b}$, then it is a.) If this is so, the problem of traditional logic vanishes here in which the nominative case must be used.

Again Indian logic deals chiefly with universal affirmative judgements and usually, universal negative judgements are rewritten as universal affirmative judgements. (e. g. anityah śabdah) Again it does not allocate a special position to particular judgements. This gave the impression that Indian logic was inaccurate, however, this cannot be said absolutely, as these four kinds of distinctions also disappear in our modern day logic. And needless to say these distinctins of judgements are possible to exprees in logical algebra.
A All a is $b$ :
$\mathrm{a} \subset \mathrm{c} ; \mathrm{ab}=\mathrm{a} ; \mathrm{a}-\mathrm{b}=0$.
E No $a$ is $b$ :
$\mathrm{a} \subset-\mathrm{b} ; \mathrm{a}-\mathrm{b}=\mathrm{a} ; \mathrm{ab}=0$.
I Some $\mathrm{a}$ is $\mathrm{b}$ :
$a-b \neq a ; a b \neq 0$.
O Some $a$ is not $b$
$a b \neq a ; a-b \neq 0$.

(Here $a$ and $b$ destignate, not sentences, but classes, and 0 designates null-class.)

However these designated four kinds of distinctions are merely some of the many possibilities and do not specially assert any important significance. Again in logical algebra universal judgements that have non-actualities as the subject (as in $\mathrm{O}$ ) are true. However particular judgements are invalid, and immediate inferences of this kind are repudiated. However in logistics the problem of true or fales being excluded, immediate inferences are established.

$$
\begin{gathered}
(x) . \varphi x \cdot \supset(\text { ( } \exists x) . \varphi x \\
\varphi a . \varphi b . \varphi c . \cdots \cdots: D \varphi(11)
\end{gathered}
$$

that is

However it does not deal with names that are immediate inferences. (And then in logical algebra to express inferences which contain particular judgements, it does not set up a special category of particulars.)

(8) ib. p. 67.

(9) ib. p. 51. cf. p. 58.

(10) ib. pp. 62-64.

(11) ib. p. 94. 
(5) Buddhist Logic Expounded by means of Symbolic Logic (H. Nakamura)
For example.
EIO
$a b=0 . \quad b c \neq 0 . a-c \neq 0$.

Speaking with regard to particular jusdgements, chiefly in Chinese and Japanese particular judgements are usually expressed in the form of the existential judgements. For example: 有人日, “hito ari, iwaku"="a certain person said....." or "There is a person who said....." ; " hanami ni yuku hito mo aru "=" there are persons who go flower gazing." (=some persons go flower gazing.)

However according to logic, if " $x$ " is "person" and " $\varphi$ " is "go flower gazing", then it is expressed by

$$
\text { ( } \mathrm{G} x) . \varphi x . \equiv \sim(x) \sim \stackrel{(13)}{\sim} \text {. }
$$

In language expression this context can be expressed as a particular judgement or an existential judgement. If it is so, then criticsm by some Westernized intellectuals cannot be leveled against the chinese and the Japanese that their language expression is illogical. Next when mediate inferences are looked into, the fact that there are two forms of expression in assertive propositions, namely conclusions, of Indian syllogism, has already been shown by Schayer.

One is "What has smoke is something that has fire" (ya yo dhümavān, so 'gnimān)

The other is "Where there is smoke there is fire" (yatra yatra dhumas, tatra taträgnih).

In traditional logic originating in Aristotle and completed in the Medieval Ages only the former is dealt with. The latter had to be written as in the former case as an universal affirmative judgement (A), or otherwise it had to be written in the form of a hypothetical judgement. From the standpoint of symbolic logic, however, the latter can be explained while keeping to its original form. The five members of the syllogism can be explained by the following examples: ( $\alpha=$ the hill, $\psi=$ fire, $\varphi=$ smoke.)

(1) The proposition (pratijña) $\psi \alpha \alpha$ The hill is on fire.

(12) ib. p. 61. cf. p. 101.

(13) ib. p. 93.

(14) Schayer: op. cit. 
(2) The reason (hetu) $\quad \phi \alpha$ Because it smokes.

(3) The explanatory example (udāharana)

( $x) \varphi x . \supset \psi x$. $\quad$ Whatever shows smoke shows fire.

For any $x$, the following rule applies :

When there is smoke in $x$, there is also fire in $x$. e. g. in a kifchen.

(4) The application (upanaya) So is this hill.

$\varphi \alpha . \supset \psi \alpha$.

This rule applies also when $x=\alpha$ (this hill, pakșa)

(5) The statement of the con- Therefore this is on fire. clusion (nigamana)

The rule applies also to $x=\alpha$ and because the statement $\varphi \alpha$ is true, therefore the statement $\psi \alpha \alpha$ is also true.

In the past, research of Indian logic has been studied based on Western traditional logic. Therefore it was thought to have a five-membered syllo. gism was redundant and in actuality only three forms were necessary. However, if interpreted using symbolic logic, it becomes clear that these five forms can be placed into their niche and are not superfluous at all.

If the above arguments are condensed into one conditional sentence it can be expressed in the following manner. (Russell's theory of apparent variables)

$$
(x) .[\varphi x . \supset \psi x] . \supset[\varphi \alpha . \supset \psi \alpha] \text {. or }\{(x)[\varphi x . \supset \psi x] . \varphi \alpha\} \supset \psi \alpha \text {. }
$$

If against the whole value of the variable $x$, in the stated function $\varphi$, the stated function $\psi$ is included in its definition, then the statement $q \alpha$ includes the statement $\psi \alpha$. In regards to the aforesaid Indian problem, the variables can be defined as:

$$
\varphi=\text { Upon } \cdots \cdots \text { is smoke } \quad \psi=\text { Upon } \cdots . . . \text { is fire } \quad \alpha=\text { this mountain. }
$$

The aforesaid detailed forms of the five-membered syllogism condensed into one conditional sentence is what is shown here, and in my opinion this is none other than would be called Dignāga's reform of logic. The method of Buddhist logic after Dignāga was not the three-sentenced syllogism like that of Western formal logic but most of the time the 
(7) Buddhist Logic Expounded by means of Symbolic Logic (H. Nakamura)

three-membered syllogism was expressed by one sentence. As Schayer has already indicated, the reasoning of Aristotle is an implication between two subsumptions. (namely one is SaM. and the other SaP.) However Indian reasoning results from the implication between two declarations. (Namely one side is $\varphi x \subset \psi x$ and the other is $\psi \alpha$.)

Aristotle's reasoning SaM. MaP. $\supset$ SaP.

Indian logic $\quad(x) .[\phi x \supset \psi x.] \supset .[\phi \alpha . \subset \psi \alpha]$.

(15) In symbolic logic, the universal affimative judgement (A) of the tradititional logic of the past is no more than one of the many possibilities established between two concepts. Thus it is expressed by the little letter ' a' by some of the logicians. According to Prof. Gohaku Sueki, it is also used by Bochenśki: Ancient Formal Login. North Holland 1953. However it is not in use by most of the present day logicians.

\section{II}

Let us see what will be the results when the modern day logic is applied to an understanding of voidness (Ś $\bar{u} n y a t \bar{a}$ ).

(1) In the philosophical literature of India, there are very many statements which are composed of complex sentences using many relative pronouns. These are veny difficult to rewrite in the forms and expressions of Western traditional logic, and again these expressions of the Sanskrit text must be strained and forced to fit. In symbolic logic, however, these can be interpreted comparatively easily. Nāgārjuna, the Buddhist philo. sopher (c. 150-250, A. D) for example asserts the following: "When there is an ' $x$ ' which depends upon ' $y$ ' (= when an ' $x$ ' has some relation with an ' $y$ '), it cannot be said that ' $y$ ' is different and apart from ' $x$ '. (Yat pratītya ca yat, tasmād anyan nopapadyate. "Madhyamaka-śāstra" IV, 5) Such a proposition can be expressed as: $(x, y) . x \mathrm{R} y \cdot \supset \sim(x \neq y)$. (When $x$ is related to $y$, it is fallacious to say that $x$ is different from $y$.) This point has already been indicated by Schayer. However the "Madhyamaka-śāstra" throughout asserts that two things which are mutually related to each other are not one and also at the same time not different. Thus the theory

(1) Schayer : op. cip. 
Buddhist Logic Expounded by means of Symbolic Logic (H. Nakamura)

of dependent origination (pratityasamtpa $\bar{d} a$ ) that is the basic standpoint of the "Madyamaka-śāstra" can be expressed as follows:

$$
(x, y) \cdot x \mathrm{R} y \cdot \supset \cdot \sim(x \neq y) \cdot \sim(x=y) .
$$

This can be said to express in Buddhist dialectic the "Refutation of Things by Identity and Difference" (一異門破) of Chia-hsiang Tashin Chi-tsang (Kajōdaishi Kichizō 嘉样大師吉藏).

(II) In perusing the argumentation of Voidness in the Mādhyamika school, the laws of formal logic as well as symbolic logic are sufficiently followed in the individual disputations. For example, it demonstrates that "Nirvāna cannot be Ens and at the same time non-Ens." It also argues, "How can Nirväna represent (the place) of Ens and of non-Ens together? As light and darkness (in one spot) they cannot simultaneously be present." ('Madhyamaka-śāstra' XXV, 14) Candrakīrti explains this as follows: "Since Ens and non-Ens are mutually incompatible, they cannot possibly exist together in one place, in Nirvānaa." The law of contradiction in formal logic is being applied here. Bools expresses the statement, "Nothing can be $x$ and not $x$ at the same time", in the following manner: $x(1-x)=x-$ $x^{2}=x-x=0$. Schröder expresses it as : $\mathrm{a}(-\mathrm{a})=0=(-\mathrm{a}) \mathrm{a}$. Present day logic indicates it as $: \sim(\mathrm{p} . \sim(5)$ p). According to Schröder's logical algebra, if ' $\mathrm{a}$ ' is ' $\mathrm{a}$ ' and also nothing, then ' $\mathrm{a}$ ' is nothing. $\mathrm{a} \times 0=0$. Again, for example, it was asserted that there cannot be the present which is now passing and is said: "We do not recognize a third kind of time section which is called 'which is now passing' distinct from that which has already passed

(2) Th. Stcherbatsky: The Conception of Buddhist Nirvana. Leningrad. p. 200. The Sanskrit original runs as follows: bhāväbhavvayor api parasparaviruddhayor ekatra nirvāne nāsti saṃbhava iti. Madhyamaka-vrtti, ed. by Louis de La Vallée Poussin. Śt.-Pétersbourg, Imprimerie de l'Académie Impériale des Sciences, 1913. Bibliotheca Buddhica IV, p. 532, l. 9) This argument is used again by Śankara against the Saptabhanginaya of Jainism. na hy ekasmin dharmini yugapat sad-asattvādiviruddhadharma-samāveśah sambhavati śìtoṣnavat (ad Brahma-sütra II, 2, 33. Ānandāśrama Sanskrit Series. Poona, The Ānandāśrama Press, 1900. Vol. I, p. 594, l. 4)

(3) Lewis and Langford: op. cit. p. 11.

(4) op. cit: p. 30. cf. p. 33.

(5) op. cit : p. 35.

(6) op. cit: p. 29 . 
(9) Buddhist Logic Expounded by means of Symbolic Logic (H. Nakamura) and that which has not yet passed." This argument is disputed according to the law of the excluded middle and Schröder indicates this by the formula : $a+-a=1$.

Nāgārjuna, then, applies in this manner the basic principles of thought and pursues his investigations. He divides into a number of domains or elements that which our existences are constituted of according to the traditional thought of Buddhism and disputes the reasons why each one of these is void. For example regarding the six sense organs (the six receptive faculties) and their corresponding six objective bases of cognition (the six sens-objects) which constitute our existence, he first argues that the organ of vision is void and made this assertion in the same manner for the other various sense organs as well as the various objective bases of cognition. Again regarding the five aggregates (skandhas) he argues on one of these, the materiel form $(r \bar{u} p a)$ and applies this argument to the other four aggregates. Based on this, the principle of non-self (anātman) which stands on the principle of Voidness was established. According to the logical algebra of Schröder this argument can be expressed in this form. If $a=0$, and $b=0 \cdots \cdots$, then $a+b+\cdots \cdots=0$.

(III) Despite the fact that Nāgārjuna's arguments clearly ahow errors from the standpoint of olden time Western traditional logic, when viewed from the standpoint of the two-valued logical algebra of Schröder, there are occasions when they are not fallacies and become true arguments.

Nāgārjuna for example says; "If there is something that is non-void, then there probably is something that is void. However there isn't anything existing that is not void. Then where is such a thing as void?" ("Madyamakaśästra' XIII, 7) This implisation is a hypothetical judgement. Therefore

(7) na ca gatāgatavyatirekena trịtyam aparam adhvajātam paśyāmo gamyamānam nāma. (Madhyamakavrtti, p. 93. l. 7)

(8) Lewis and Langford: op. cit. p. 34.

(9) "Madhyamaka-śāstra", Third chapter.

(10) "Madhyamaka-śástra”, Fourth chapter.

(11) Lewis and Langford: op. cit. p. 39.

(12) In the Prasannapada , it is explained as śūnyam=śunnyatā, aśūnyam=aśunyatā. 
Buddhist Logic Expounded by means of Symbolic Logic (H. Nakamura)

the only thing that can be implied from this proposition is the denial of the antecedent, 'There is something that is non-void' from the denial of the consequent, 'There probably is something that is void.' Nevertheless Nāgārjuna implies the denial of the consequent from the negation of the antecedent. This is an error of the law of conversion by contraposition. However from the standpoint of logical algebra, if voidness is expressed by ' 0 ', something that is void is expressed by $a \cdot 0$, and something that is non-void is expressed by $-0 \cdot b$. Then Nāgārjuna's assertion will be formulated as follows:

$(b \cdot-0)(a \cdot 0)=1$ [If there is something that is non-void, then there is something that is void.]

$\mathrm{b} \cdot-0=0$ [There is not anything existing that is not void.]

$\therefore \quad 0(\mathrm{a} \cdot 0)=1$

$-1(a \cdot 0)=1$

$1(\mathrm{a} \cdot 0)=-1=0$

$\therefore a \cdot 0=0 \quad$ [Then whese is such a thing that is void!]

Of course, this formulation of the first sentence by Nāgārjuna is logistically wrong. For,

$$
(b \cdot-0)=(b \cdot 1)=b
$$

and

$(\mathrm{a} \cdot 0)=0$

Therefore

$(\mathrm{b} \cdot-0)(\mathrm{a} \cdot 0)=\mathrm{b} \cdot 0=0 . \quad($ not $=1)$

However, what the writer of the present article wants to say is that, although the first sentence by Nāgārjuna may be wrong, when expressed with the figures of symbolic logic which designate classes, there is no fallacy with regard to conversion by contraposition; i. e. the conclusion entails no fallacy of contradicting to the first sentence set forth by Nāgārna.

The fact that the above-mentioned logistical formation as such is fallacious proves that the doctrine of voidness as such held by ancient Buddhists has something that can not be explained away by the method of symbolic logic alone.

If the concept of voidness is expressed by the figure ' 0 ', then the 
(11) Buddhist Logic Expounded by means of Symbolic Logic (H. Nakamura)

statement expressed in words, would be as follows: "Truth is that there is no such thing as is non-void nor any thing as is void. (And again any disjunctive members cannot be established aside from these.) If this is so, why is this standpoint not a fallacy when applied to logical algebra, when considered fallacious from the standpoint of logic from Aristotle thereafter. The reason for this is because the logical algebra of Schröder assumes the two-valued logical standpoint which adheres to the essential contents of the true and the false, existence and nothing.

Other arguments of Nāgārjuna can be interpreted in the same way. For example: "Perhaps if something that was not born yet could have an existence somewhere, it would probably be born. However as it is not yet existing, therefore what is it that would be born. ("Madhyamaka-śastra" VII. 17) This also violates the law of conversion by contraposition. However in logical algebra, if 'something' is indicated by a, and 'to be born' by $b$, then $a b=1 \quad \therefore-(a b)=-1$. If $a=-1$ is inserted here, then $-(-1 \cdot b)=$ -1 . $\therefore 1 \cdot b=-1$. Therefore (b) 'to be born' must be denied.

(IV) However Buddhism and the Mădhyamika school in particular states arguments which are difficult to make clear just as they stand even from the standpoint of present day logic. In the Madhyamaka-sāstra, the disputation that everything is void is occasionally explained by the traditional Buddhist's set of four alternative propositions (catușkotikāa, namely that something is, is not, both is and is not, neither is nor is not.) If perhaps the first phrase (something is) and the second phrase (is not) were not of a contradictory nature and it were permissable to more of less overlap each other extensively, then a Venn diagram can be applied. According to logical algebra it can be indicated as following:

$$
a b+(a .-b)+(-a b)+(-a .-b)=1 \text {. }
$$

However in the 'Madhyamaka-śastra', the first and the second points of argumentation are in a contradictory relation to each other. For example it says: "The Tathāgata is not permanent; nor is he impermanent; not permanent and at the same time impermanent; not not permanent nor at

(13) Lewis and Langford: op. cit. p. 53, cf. p. 42. 
the same time not impermanent. He is not finite; nor is he infinite; nor is he infinite; nor is he finite and at the same time infinite; and it is not that he is not finite and not infinite." In this case the first proposition (permanent, finite) and the second proposition (impermanent, infinite) do not overlap extensively and the second proposition (impermanent, infinite) do not overlap extensively and contradict each other. If this is the case, then the four propositions can be expressed as ' $a,-a, a(-a),-a .-(-a)$ '. If the four propositions are put together and extricated, they would be reduced as follows: $\quad a+(-a)+[a(-a)]+[-a(-a)]$

$$
\begin{aligned}
& =a+-a+0+-a a=a+-a+0+0 \\
& =a+-a=1 .
\end{aligned}
$$

In the final analysis the third and the fourth propositions of the four argumentations have no actual and substantial meaning. Because of this, the logic of the four alternative propositions (catuskotika) which was already expressed in the primitive Buddhist period actually formulates an argument that has substantially no logical meaning. Furthermore the result which is derived at the very end, ' $a+-a=1$. ', cannot be upheld as true in Voidness. Because ' a' as well as ' $-\mathrm{a}$ ' are void and its orignal word (śünya) connotes the meaning of zero in mathematics, Voidness can be expressed as the following: $\quad a+-a+a(-a)+-a-(-a)=\cdots \cdots=0+0+0+0=0$.

This was what the Mādyamika school wished to express.

"The Mādhyamika school recognizes that truth is not Ens (sat), is not non-Ens (asat), is not Ens and at the same time non-Ens, and again is not a denial of the two."

(14) Madhyamaka-śāstra, XXII, vv. 12. cf. 11. cf. XXV, 4-18; $22 ; 23$.

(15) na san nāsan na sadasan na cāpy anubhayātmakam/ catușkoṭivinirmuktam tattvam Mädhyamikā viduhll

Bodhicaryāvatārapañjikā. (Louis de la Vallée Poussin: Bouddhisme, études et matériaux.London, Luzac and Co., 1898. p. 359, ll. 10-11.)

atas tattvam sadasadubhayānubhayātmaka-catuṣkoțivinirmuktạn śūnyam eva. Sarva-darśana-saṃgraha of Säyanna-Mädhava. Ed. by Vasudev Shastri Abhyankar. Poona, the Bhandarkar Oriental Research Institute, 1924. Government Oriental Series; I. II, $l .159$. cf. $l .160 \mathrm{f}$.

"If a bodhisattva who practices prajñapāramitā adheres to (=thinks) all 
In the Mãdhyamika school, as things could not be expressed absolutely as being (Ens), and again not understood absolutely as nothing (non-Ens), the theory of the Middle way of neither Ens nor non-Ens was set forth, which is thought to carry the same purport as the theory of dependent origination(pratĩtyasamutpāda). However the Sāmkhya school raised criticisms on this point and in the "Suvarna-saptati", it is written as follows:

"We will refute at first the opinion of Śākyamuni, then later that of Vaiśeșika. The opinion of Śākyamuni 'neither existing nor non-existing' is inadmissible because it is contradictory with itself. If it is inexistent it is to say it is nothing. If it is not inexistent then it is to say this is existing. To hold existence and non-existence together cannot be held because they are contradictory. It is as to say for example, "This man is dead and again living (at the same time)'. As this statemant is in contradiction with itself, it can not be maintained. This argument also can be applied to the doctrine of Śākyamuni."

Against this Paramārtha replies:

“The master of the Tripitaka (Paramārtha) says that this (above) refutation cannot be held. Why? Because Saakyamuni did not have such

phenomena (sarve dharmāh) as existent, as non-existent, as existent and nonexistent at the same time, or as non-existent and not non-existent at the same time, or if he adheres to not-adhering, he does not, in actuality, practice prajñäpäramita." “若菩薩摩訶薩修行般若波羅蜜多時. 於一切法. 若取有. 若取非有. 若取亦有亦非有. 若取非有非非有. 若取不取. 非行般若波羅餐多.” (Prajña-pāramitāsūtra; chapter 41, Taisho Tripițaka, Vol. 5, page 229 b.) etayā catușkoțikayā Mahāmate rahitāh sarvadharmā ity ucyante. (Laìkāvatāra-sütra, ed. by B. Nanjio, Kyoto, the Otani University Press, 1923, p. 122, $l l .2-8$. )

"If we pursue things by discriminative knowledge, there is no ens, no non-ens, no ens and non-ens at the same time, no non-ens and not non-ens at the same time. This is the reality of all pnenomena. This is suchness (tathat $\bar{a}$ ), natural condition (dharmatā), the true end (bhütakoți), nirvāna". “分別推求諸法. 有亦無. 無亦無. 有無亦無. 非有非無亦無. 是名諸法實相. 亦名如 法性. 實際涅槃.” (Piñgala's Commentary upon Nāgārjuna's Madhyamaka-śāstra.) Taisho Tripițaka, Vol. 30, p. 36 b.)

sad asat sad asac ceti yasya pakșo na vidyatel

upālambhaś cirenāpi tasya vaktum na śakyatell

(廣百論本) The Chinese version of the Larger Śataśästra,VIII, v. 25. cited in Madhyamakavrtti, p. 16. 
an argumentation. If Śākyamuni preached 'inexistence', (it did not mean) he adhered to 'nothing'. (If) Sākyamuni preached non-inexistence, (it did not mean) he held to existence. (Śākyamuni's view) is apart from holding to either of the two extremes. Therefore the (Sämkhya argument) is not effective."

As opposed to the Sāmkhya school which adhered to the rules of the law of contradiction and the law of the excluded middle, Buddhism held to a different thought. This controversy corresponds to that in modern days between those logicians who strictly adhere to formal logic or logical positivism and those who abvocate dialectic.

In conclusion, one problem still remains. That is to say w whether the original word of voidness (śunya) which connotes zero has the same meaning as that of the 0 of the logical algebra. The valuation of authenticity is excluded is excluded in present day logical calculations. Therefore nothing is expressed by ' 0 ' in logical algebra, because it is based on the standpoint of a two valued logic. All that does not exist is expressed by ' 0 ' and is called the 'null class', indicating something that cannot exist and expressing falsehood. Opposed to this ' 1 ' carries the meaning of truth. Therefore,

(16) Ad The Suvarna-saptati v. 9.

Takakusu translated this passage as follows:

Répondant à cela, nous réfuterons l'opinion de Çākyamuni, ensuite celle des Vaiçeșikas. L'opinion de Çākyamuni, "ni existent ni inexistant, est inadmissible, parce qu'elle est contradictoire avec elle-même. Dire inexistant, cela veut dire le néant; dire non inexistant, c'est dire existant. Existence et.non-existence ensemble font une contradiction; c'est comme si vous disiez; tel homme n'est ni mort ni vivant. Comme cette opinion est en contradiction avec elle-même, elle ne peut être maintenue. Ainsi en est-il de la doctrine dé Çākyamuni.

“ Note de Paramārtha.- Cetse réfutation (c'est-à-dire la dernière phrase) est fausse. Pourquoi ? Parceque Çākyamuni n'avait pas une telle opinion. Quand Çākyamuni affirme l'inexistence, cela ne veut pas dire le néant. Il ne veut pas dỉre non plus existence quand il dit que ce n'est pas inexistant, car il n'insiste sur aucun des deux extrêmes. La réfutation n'atteint donc en rien le Bouddhisme."

J. Takakusu : La Sāmkhyakārikā étudiée a la lumière de sa version chinoise. Bulletin de l'École Française d'Extrême-Orient. Janvier-Juillet et OctobreDécembre 1904. Hanoi 1904, pp. 77-78.

(17) Lewis and Langford: op. cit. p. 28. 
(15) Buddhist Logic Expounded by means of Symbolic Logic (H. Nakamura)

within these limits, it must be permitted after all to indicate Voidness by ' 0 '. There are, however, aspects in Voidness that contradicts with symbolic logical thought and again phases that cannot be expressed by it. A big problem remains as to whether this can be dealt with in a multi-valued logic or whether it can be solved in dialectic. The elucidation of this topic will be reserved for a later date.

\section{Part II : DIGNĀGA'S LOGIC EXPOUNDED BY MEANS \\ OF SYMBOLIC LOGIC}

To expound the logical theories of Dignāga and other Buddhist philosophers by means of symbolic logic seems much more reasonable and adequate. In substance there must be little difference between the Western and Buddhist logical theories. In the following we shall investigate into some theories characteristic of Dignāga.

The theory of the three characters of a valid middle term was adopted and fully established by Dignāga. A verse as is identified from Chapter II of his Pramannasamuccaya runs as follows:

anumeye 'tha tat-tulye sadbhāvo nāstitā 'sati.

E. Tr. "The presence only (never non-existence) of the middle term in the subject of the inference; the presence of the middle term in things, in which the property to be proved is present; and the non-presence of the middle term in things, in which the property to be proved is present."

In the technical language of a later age these three were represented as: pakșadharmatā, sapakṣa eva sattvam, and vipakșe cāsattvam. If we express these three with the signs S, M, P in traditional formal logic, or with $\alpha$, $\varphi$, and $\psi$ in symbolic logic, they have to be expressed as follows:

(1) pakșadharmatā $\alpha \varphi$

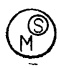

(1) H. N. Randle: Fragments from Dinnāga. The Royal Asiatic Society, London, 1936 p. 23. 
Buddhist Logic Expounded by means of Symbolic Logic (H. Nakamura)

(2) sapakșa ava sattvam $\varphi \psi$

(3) vipakṣe cāsattvam

$\sim[\varphi(\sim \psi)]$
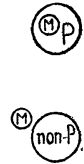

The theory of the nine reasons or types of argument, which are valid and invalid, were set forth by Dignäga. The theory was propounded in his Nyäyamukha of which the Sanskrit original was lost and the two Chinese versions have been preserved up to present days. Sanskrit fragments of the work, however, have been preserved in later works as citations. Vācaspatimiśra cites two verses of the Nyãvamukha as follows:

atra Dinnāgena

sapakșe sann asan dvedhā pakșadharmah punas tridhāl

pratyekam asapakṣe ca sad-asad-dvividhatvátah/l

iti nava pakṣadharmān hetu-tadābhāsān darśayitvā

tatra yah san sajātīye dvedhā căsams tadatyayel

sa hetur viparīto 'smäd viruddho 'nyas tv aniścitahll

iti hetu-tadābhāsaviveko darśitah.

E. Tr. "Dinnāga says:

'A middle term or quality of the subject of inference first takes three forme, according as it does or does not reside in the two dossible ways in the sapakșa.'

'And in each of these three posssible cases the middle term does or does not reside in the two ways in the vipakșa.'

"So saying he has shown the nine middle terms (lit. qualities of the subject of inference), of which some are valid reasons and the others are fallacious:

'Among these, a middle term which is either (1) present in the

(2) The Nyāyavārttika-tātparyațīkā, ed. by Rajeshwara Sastri Dravid. Benares, Chowkhamba Sanskrit Series Office, 1925, 26. Kashi Sanskrit Series, 24. p. 289, ll. 15-21. Hakuju Ui: Studies in Indian Philosophy, vol. V, Tokyo, Koshisha, 1924, pp. $561 ; 592$.

(3) anyatvaniścitah in the text of the Chowkhamba Sanskrit Series. But corrected according to the Nyāyamukha. Cf. H. Ui:'op. cit. vol. V, p. 594. 
(17) Buddhist Logic Expounded by means of Symbolic Logic (H. Nakamura)

sapaksa or (2) present and absent in the sapaksa, and is absent in the vipakșa, is a valid reason. Whatever contradictory to this is a contradictory reason. What differs from these is inconclusive, i. e. not leading to any conclusion.'

In these lines the distinction between the reason or valid middle, and the apparent reason or invalid middle, is shown."

The two verses cited in the preceding passage are translated in the Chinese versions of the Nyāyamukha (因明正理門論) as follows:

“宗法於同品，謂有非有俱，於異品各三，有非有及二.”

and “於同有及二，在異無是因，覾此名相違，所餘皆不定.”

With regard to the nine reasons or types of argument, we shall express the reason with $\varphi$, sapakșa with $\psi$, and vipakșa with $\sim \psi$. Then both presence in sapakșa and presence and non-presence in sapakșa are expressed with the formula $\varphi \psi$. In the case of presence and non-presence in sapakșa, $\varphi \subset \psi$ is implied. The presence only in sapakșa in the cases of the first and second type of reasoning is regarded as a peculiar case in the limit, i. e. $\phi=\psi$. The presence only in vipakșa also has to be regarded as a peculiar case in the limit ò presence and absence in vipakșa. When $\varphi$ is present in either $\psi$ or $\sim \psi$, the dot. should be used, and when it is present in both of them which are themselves disjunctive (exclusive) to each other, the sign + should be used. (Such signs as $\alpha, \varphi, \psi$ etc. designate classes (Klassen). They are not used from the standpoint of propositional logic(Aussagenlogik)]

I, present in sapakșa and present in vipakșa-inconçlusive.

$$
\begin{aligned}
& \phi \psi+\phi(\sim \psi) \\
= & \phi \psi+\sim(\varphi \psi) .
\end{aligned}
$$

II, present in sapakșa and absent in vipakșa-valid.

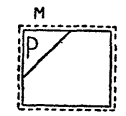

$$
\begin{aligned}
& \phi \psi \cdot \sim\{\phi(\sim \psi)\} \\
= & \varphi \psi \cdot \sim\{\sim \varphi \psi\}=\phi \psi \cdot \phi \psi=\phi \psi
\end{aligned}
$$

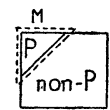

III, present in sapakșa, and present and absent in vipakșa.-inconclusive.

$$
\begin{aligned}
& \varphi \psi+\varphi(\sim \psi) \\
= & \varphi \psi+\sim \varphi \psi
\end{aligned}
$$

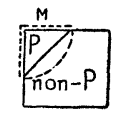

IV, absent in sapakșa and present in vipakșa-contradictory. 
Buddhist Logic Expounded by means of Symbolic Logic (H. Nakamura)

$$
\begin{aligned}
& \sim(\varphi \psi) \cdot \varphi(\sim \psi) \\
= & \sim(\phi \psi) \cdot \sim(\phi \psi)=\sim(\varphi \psi)
\end{aligned}
$$

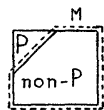

$\mathrm{V}$, absent in sapakșa and absent in vipakșa-inconclusive.

$$
\begin{aligned}
& \sim(\varphi \psi) \cdot \sim \varphi(\sim \psi) \\
= & \sim(\varphi \psi) \cdot \sim(\varphi \psi)
\end{aligned}
$$

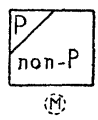

Or this can be formulated as follows:

$$
\begin{aligned}
& \{\phi(\sim \psi)\} \cdot[\varphi\{\sim(\sim \psi)\}] \\
= & \sim \phi \psi \cdot \phi \psi=\sim \phi \psi
\end{aligned}
$$

VI, absent in sapakșa, and present and absent in vipakșa.-contradictory.

$$
\begin{aligned}
& \sim \varphi \psi \cdot(\varphi \cdot \sim \psi) \\
= & \sim \varphi \psi \cdot(\varphi \psi)
\end{aligned}
$$

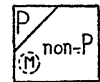

VII, present and absent in sapakșa, and present in vipakșa-inconclusive.

$$
\begin{aligned}
& \varphi \psi+\varphi(\sim \psi) \\
= & \varphi \psi+\sim \varphi \psi
\end{aligned}
$$

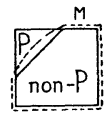

VIII, present and absent in sapakșa, and absent in vipakșa-valid.

$$
\begin{aligned}
& \phi \psi \cdot \sim\{\phi(\sim \psi)\} \\
= & \phi \psi \cdot \varphi \psi=\phi \psi
\end{aligned}
$$

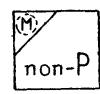

IX, present and absent in sapakșa, and present and absent in vipakșainconclusive.

$$
\begin{aligned}
& \varphi \psi+\varphi(\sim \psi) \\
= & \varphi \psi+\sim \varphi \psi
\end{aligned}
$$

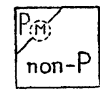

Here we are led to an interesting conclusion, having expressed the nine reasons or types of argument by means of signs of symbolic logic and extricated them by means of logical calculation. All the valid reasons are expressed with $\varphi \psi$. viz.: "If $\varphi$, it must be $\psi$ ". All the contradictory reasons are expressed with $\sim \varphi \psi$, viz.: "If $\varphi$, it must not be $\psi$ ". All the inconclusive reasons (except the fifth type) are expressed with $\varphi \psi+\sim \varphi \psi$, viz.: "If $\varphi$, it must be either $\psi$ or non- $\psi$. It is undecided whether it is true or false. We can not say that, if $\phi$, it must be always $\psi . "$

Formulae in symbolic logic are always convertible unlike those in traditional formal logic. From the three fundamental formulae, $\varphi \psi, \sim \varphi \psi$, and $\varphi \psi+\sim \varphi \psi$ we can deduce eight of the nine reasons or types of 
(19) Buddhist Logic Expounded by means of Symbolic Logic (H. Nakamura)

argument, and also other formulae besides the nine.

The only remaining problem is the fifth type. If we apply symbolic logic to it, it must be regarded as false, and not inconclusive. From the viewpoint of the traditional formal logic of the West, it corresponds to the fallacy of irrelevant conclusion. Dignāga, the Buddhist logician, however, defined it inconclusive, illustrating this with a syllogism: "Sound is eternal, because audible." Why is it that what has been regarded as false in Western logic was regarded as inconclusive by Dignāga? It seems that it is due to the traditional Buddhist attitude of assuming 'neither being, nor nonbeing' (in the catușkotika, a set of four alternative propositions) as a logical mode which differs from being and non-being. In so far as we stick to the principle of contradiction, we can not admit the possibility of such a mode. When we express it in symbolic logic. 'meither being, nor nonbeing' must be as follows :

$$
(\sim \varphi) \cdot \sim(\sim \varphi)=\sim \varphi \cdot \varphi=\sim \varphi
$$

So, 'neither being, nor non-being' comes to be the same as 'non-being'. The concept of catuṣkotika either can not be admitted from the standpoint of the principle of contradiction. Dignāga's attitude of regarding the fifth type not as false, but inconclusive, was influenced by the philosophy of śünyatā or of catuṣkoțikā which admitted 'neither being, nor non-being' as a peculiar mode of existence.

Anyhow, the logic of the nine types of argument is a peculiar logic from the viewpoint of symbolic logic. In so far as it is aimed at explaining by means of the concepts of sapakșa and vipakșa it is a consummated one in a specific age of history of thought.

The Vaiśeșikas and Naiyāyikas admitted the existence of universals in their own ways. This tendency was conspicuous in the Sarvāstivādins among the Buddhists. Such a way of thinking was highly attacked by the Mādhyamikas. Dignāga asserted that they were nothing but fictions by our intellect. On this point Dharmakīrti, his successor, said as follows:

(4) The Nyäyamukha. H. Ui: op. cit. vol. V. p. $589 \mathrm{f}$.

(5) The Pramānavārttika, ed. by Rāhula Sāṃkṛtyāyana, p. 13. 
Buddhist Logic Expounded by means of Symbolic Logic (H. Nakamura)

na yāti na ca tatrāsĩd asti paścān na cāmśavt// (Pramānavāarttika, I, 153 cd) jahāti pūrvam nādhäram aho vyasanasaṃtatị̆| anyatra' vartamānasya tato ['nyasthānajanmanil/ $(\mathrm{I}, 154)$ svasthänäd acalato 'nyatra vrttir] ayuktimat| yatrāsau vartate bhävas tena sambadhyate pi na/l $(\mathrm{I}, 155)$ taddeśinam ca vyāpnoti kim apy etan nädbhutam// (I, $156 \mathrm{ab)}$

(A universal, e. g. jar-ness,) does not go out (of clay of a jar), and it was not there (in a jar) before. It does not come into existence later.! It does not consist of parts. (I, $153 \mathrm{~cd}$ )

It does not quit its former receptacle. What a series of difficulties ! It is not reasonable that what (as a universal, e. g. jar-ness) in one place (i. e. a jar) should, without moving from that place, reside in what comes to exist in a place other than that place.

(Jar-ness) is not joined with the place (i. e. ground) where the thing in question (i. e. a jar) is; and yet (they say that) (jarness) does not fail to prevade the thing (i. e. a jar) which is in that place (i. e. ground). Is not this very wonderful ?"

These verses are cited in the Sarvadarśanasamgraha (II, $l .135 \mathrm{f}$.) with some modifications. One of these verses was ascribed to Dignāga by Dharmabhūṣaṇa, the Jain logician.

Dignāga denied the existence of universals, and asserted that they were nothing but fictions constituted merely by excluding what is other (apoha). According to him words express only relations or mutual negation; a concept is made only by negating what is other than it. From the viewpoint

(6) in stead of nädbhutam, mahādbhutam (Sarvadarśanasamgraha, II, l, 136; Manorathanandin).

(7) S. C. Vidyabhushana: History of Indian Logic, pp. 273-274 n;; H. N. Randle: op. cit. p. 59 .

(8) The theory of apoha was set forth in the fifth chapter of the Pramanasamuccaya (cf. S. Ihara, Bunka, XV, No. I, 1951, p. $14 \mathrm{ff}$.; Tetsugaku Nenpo, XIV, p. $101 \mathrm{f}$.); in the Pramanavārttika, III, v. $163 \mathrm{f}$. Cf. A. B. Keith : Indian Logic and Atomism, p. $106 \mathrm{f}$; S. Mookerjee: The Buddhist Philosophy of Universal Flux, pp. 110-139; H. Ui: Toyo no Ronri, p. 200 f.; Y. Kanakura: Indo Chusei Seishinshi, vol, I, p. 75 f.; E. Frauwallner; WZKM, 42. 
(21) Buddhist Logic Expounded by means of Symbolic Logic (H. Nakamura)

of symbolic logic this theory can be formulated as follows:

$$
p=\sim(\sim p)
$$

In this respect that a universal is regarded as being established with negation as its momentum, we find an influence by the philosophy of súnyatã. The conception of apoha should be the more esteemed considering the fact that such an advanced logician as Prof. Quine wants to deduce all processes of logical thinking to denial and conjunction.

(9) W. van O. Quime: Elementary Logic, 1941. To illustrate, the sentence : If $\mathrm{J}$ or $\mathrm{S}$ then neither $\mathrm{A}$ nor $\mathrm{M}$ and $\mathrm{D}$ unless $\mathrm{C}$ and $\mathrm{T}$ is expressed as follows : $\sim(\sim(\sim \mathrm{J} . \sim \mathrm{S}) . \sim \sim(\sim \mathrm{A} . \sim(\mathrm{M} . \mathrm{D})) . \sim(\mathrm{C} . \mathrm{T})))$

PS. The first part of this article was once published in the Journal of Indian and Buddhist Studies (Indogaku Bukkyogaku kenkyu), vol. III, No. 1, September 1954, pp. 223-231 (in Japanese). Recently Professor Robinson of University of Toronto, Canada, referred to, and reviewed,-this article, in Philosophy East and West, published by the University of Hawaii Press, vol. VII. 1958. Taking advantage of this occasion, I have published the English traslation of this article which has been rendered by Mr. Akira Hata into English and checked by the author.

The second part is originally a part of the author's article "The Influence of the Philosophy of Voidness on Hetu-vidyā Logic," published in The Fundamental Truth of Buddhism edited by Prof. Shoson Miyamoto, Tokyo, Sanseido, 1956. This article was written in Japanese, and has newly been translated into English, and added here, by the author.

This article is no more than a trial paper, but regrding symbolic logic, the writer has received valuable suggestions and advice from Professors J. D. Goheen, J. Suetsuna, S. Tsurumi, and in specialized problems, he received the helpful advice and information by Professors G. Sueki and S. Ichii. At the end of this work, he would like to express his deep appreciation to them. 